\title{
Analisis Jaminan dalam Akad-Akad Bagi Hasil (Akad Mudharabah dan Akad Musyarakah) di Perbankan Syariah
}

DOI : $10.30595 /$ jhes.v\%vi\%i.9903

Aufa Islami

Fakultas Syariah dan Hukum UIN Sunan Kalijaga Yogyakarta, Email: Islamiaufa12@ gmail.com

\begin{abstract}
Abstrak
Penelitian ini dilakukan dengan tujuan untuk menganalisis jaminan yang terdapat dalam akad-akad bagi hasil, diantaranya akad mudharabah dan akad musyarakah yang terdapat di Perbankan Syariah. Penelitian artikel ini menggunakan pendekatan normatif. Pendekatan normatif digunakan untuk riset dari perspektif fikih muamalat tentang kedudukan jaminan dalam akad bagi hasil. Penelitian ini menunjukkan bahwa pada dasarnya tidak ada jaminan atas akad-akad bagi hasil, seperti mudarabah dan musyarakah, kecuali sebagai jaminan atas kemungkinan adanya moral hazard (bahaya moral) yang dilakukan oleh mitra akad. Dalam praktik, lembaga-lembaga keuangan syariah, khususnya perbankan syariah, selalu menarik jaminan kebendaan atas akad-akad bagi hasil yang ditutupinya bersama mitranya (nasabahnya). Tetapi harus diingat bahwa penarikan jaminan kebendaan tersebut haruslah dibatasi pada kasus-kasus di mana adanya kerugian karena perbuatan melanggar hukum, kealpaan atau cedera janji yang dilakukan oleh nasabah. Dalam hal kerugian terjadi di luar kesalahan, kealpaan, atau pelanggaran kontrak oleh nasabah, maka jaminan tidak boleh dieksekusi.
\end{abstract}

Kata-kata kunci : Jaminan, Mudharabah, Musyarakah

Abstract

This research was conducted with the aim of analyzing the guarantees contained in profit sharing contracts including the Mudharabah contract and the Musyarakah contract in Islamic Banking. This article research uses a normative approach. The normative approach is used for research from the perspective of figh muamalat regarding the position of the guarantee in the profit sharing contract. From this research it can be concluded that basically there is no guarantee for profit sharing contracts, such as mudarabah and musyarakah, except as a guarantee of the possibility of moral hazard being carried out by the contract partners. In practice, Islamic financial institutions, 
especially Islamic banking, always withdraw material guarantees for the profit sharing contracts they cover with their partners (customers). However, it must be remembered that the withdrawal of the material guarantee must be limited to cases where there is a loss due to unlawful acts, negligence or default by the customer. In the event that the loss occurs beyond the customer's fault, negligence or breach of contract, the guarantee may not be executed.

Keywords: Guarantee, Mudharabah, Musharaka

\section{Pendahuluan}

Secara umum bentuk-bentuk pembiayaan yang didanai oleh bank syariah adalah jual beli, sewa, bagi hasil dan penyertaan modal atau kemitraan. Jangka waktu pembiayaan disepakati oleh pihak bank dengan nasabah debiturnya dengan mempertimbangkan kemampuan pengembalian pembiayaan tersebut. Pembiayaan dapat disetujui oleh bank bila nasabah menyertai permohonan dengan jaminan (collateral) yang layak. Jaminan tersebut berupa harta benda milik debitur atau pihak ketiga yang diikat sebagai alat pembayar jika terjadi wanprestasi terhadap bank syariah. Jaminan yang diberikan oleh debitur kepada bank syariah dibutuhkan untuk pembayaran hutang seandainya terjadi waprestasi terhadap pembiayaan yang telah diberikan oleh bank dengan cara menguangkan atau menjual jaminan tersebut melalui mekanisme yang telah ditetapkan. Untuk mengantisipasi kerugian yang mungkin saja timbul dalam kegiatan pembiayaan, bank harus menetapkan kebijakan sebagai langkah antisipatif sedini mungkin, yaitu sejak mempertimbangkan memberikan pembiayaan yaitu dengan adanya jaminan yang dimiliki oleh nasabah.

Penelitian terdahulu yang menggunakanjaminan dalam akad mudharabah, dan musyarakah dalam perbankan syariah pernah diteliti oleh beberapa peneliti. Hasil penelitian Muhyidin, Muhammad Mukhtar Shidiq dan Triyono (2017), pandangan hukum positif mengenai pembebanan jaminan pada akad mudharabah di perbankan syariah Indonesia adalah pengaturan yang ada terkait dengan pembebanan jaminan masih menggunakan konsep rahn, hal tersebut masih bersifat umum dan hanya berdasarkan fatwa dari Dewan Syariah Nasional (DSN-MUI), hal demikian terjadi akibat belum adanya ketentuan perundang-undangan yang secara khusus mengatur tentang hal ini, akibatnya adalah pembebanan jaminan ( $\mathrm{rahn}$ ) dalam perbankan syariah 
Indonesia justru menggunakan ketentuan dari KUH Perdata tentang gadai dan hipotek serta Undang-undang Hak tanggungan dan Undang-undang Fidusia yang notabene merupakan pengaturan hukum jaminan untuk perbankan konvensional (perjanjian utang piutang). Sementara pandangan hukum Islam mengenai pembebanan jaminan pada akad mudharabah di perbankan syariah adalah hukumya haram membebankan jaminan pada akad mudharabah. Karena pendapat yang paling kuat adalah pendapat dari para ulama tentang haramnya pembebanan jaminan pada akad mudharabah baik mudharabah perorangan maupun mudharabah musytarakah, maka jelaslah bahwa pembolehan pembebanan jaminan pada akad mudharabah musytarakah maupun akad mudharabah perorangan dapat mengubah transaksi mudharabah menjadi transaksi riba yang dilarang dalam hukum Islam. Lagi pula persyaratan pembebanan jaminan ini membuat akad mudharabah-nya menjadi batal dan diragukan keabsahannya (Muhyidin, 2017).

Penelitian yang dilakukan oleh Sawitri Putri Nursakti (2018), pembebanan agunan/jaminan kepada nasabah tersebut, juga berlaku pada Bank Muamalat Indonesia Cabang Samarinda. Bank Muamalat meminta jaminan yang bernilai ekonomis dan sesuai dengan jumlah transaksi yang dilakukan sebagai pegangan. Bank Muamalat juga menerima jaminan berupa hak atas tanah (hak tanggungan) dari nasabah. Tujuan dari pembebanan jaminan terhadap nasabah kreditur sebagaimana tercantum dalam penjelasan Pasal 8 ayat (1) Undang-undang No.10 Tahun 1998 tentang Perbankan, menyatakan sebagai berikut: “Kredit atau pembiayaan berdasarkan Prinsip Syariah yang diberikan oleh bank mengandung risiko, sehingga dalam pelaksanaannya bank harus memperhatikan asas-asas pengkreditan atau pembiayaan berdasarkan Prinsip Syariah yang sehat. Untuk mengurangi risiko tersebut, jaminan pemberian kredit atau pembiayaan berdasarkan Prinsip Syariah dalam arti keyakinan atas kemampuan dan kesanggupan Nasabah debitur untuk melunasi kewajibannya sesuai dengan yang diperjanjikan merupakan faktor paling penting yang harus diperhatikan oleh bank. Untuk memperoleh keyakinan tersebut, sebelum memberikan kredit, bank harus melakukan penilaian yang seksama terhadap watak, kemampuan, modal, agunan, dana prospek usaha dari nasabah debitur".(Nursakti, 2018) 
Penelitian Fajar dan Yanto (2018), BMT memberikan kelonggaran kepada nasabah dalam melakukan pembayaran apabila nasabah dianggap tidak mampu melakukan pembayaran. Pembayaran yang dituntut pada akhirnya hanya meminta pembayaran pada utang pokok dan tidak lagi mengharapkan pembagian hasil usaha yang telah dilakukan oleh nasabah. Apabila dalam perjanjiannya mensyaratkan jaminan, maka barang yang menjadi jaminan akan dieksekusi bersama nasabah yang memilii hak pada jaminan tersebut. Hasil eksekusi akan dikembalikan kepada nasabah. Mekanisme penjualan barang jaminan pada BMT UGT Sidogiri dilakukan dengan cara mempertemukan tiga pihak yaitu: pihak BMT sendiri, pembeli dan pemilik barang jaminan. Setelah barang jaminan dijual, maka akan dilakukan penghitungan jumlah dari hasil penjualan barang tersebut. Apabila hasil penjualan barang tersebut melebihi hutang nasabah maka kelebihan tersebut akan diserahkan kepada nasabah atau pemilik barang. Namun, apabila hasil dari penjualan barang yang dijaminkan oleh nasabah ternyata masih belum cukup untuk melunasi pokok pembiayaan, maka nasabah diwajibkan menambah kekurangan tersebut. (Fajar dan Yanto, 2018)

Penenelitian yang lain, Shofa Fathiyah dan Nurhasanah (2019) Jaminan kebendaan dalam bentuk Hak Tanggungan yang berupa Akta Pemberian Hak Tanggungan dalam pembiayaan musyarakah pada perbankan syariah belum sesuai dengan hukum Islam dikarenakan terdapat beberapa kewenangan di dalam akta Hak Tanggungan tersebut belum sesuai dengan ketentuan hukum Islam. Hal ini dikarenakan dalam pembiayaan di keuangan syariah tidak seluruhnya berbasis utang piutang, namun juga ada yang berbasis modal kerja dan jasa. Maka musyarakah tidak ditemukan adanya utang-piutang secara prinsip sehingga penerapan jaminan fidusia tidak kompatibel dengan model pembiayaan tersebut.(Shofa Fathiyah dan Nurhasanah, 2019). Pada Perkara Nomor 1901/Pdt.G/2016/PA.JS pihak bank mengajukan gugatan untuk penetapan sita jaminan yang seharusnya hakim dengan exofficionya melihat kembali dalam hal kecukupan jaminan hak tanggungan maupun sita jaminan. Disini terlihat adanya ketidakpastian dalam transparansi penilaian jaminan yang belum mencukupi jumlah hutang, seharusnya tergugat mendapatkan kepastian hukum dalam transparansi penilaian jaminan sita jaminan, apakah sudah mencukupi total kewajiban tergugat Pasal 4 Undang-Undang Nomor 8 
Tahun 1999 Tentang Perlindungan konsumen hak atas informasi yang benar, jelas, dan jujur. (Shofa Fathiyah dan Nurhasanah, 2019)

Prosedur Eksekusi Hak Tanggungan akad musyarakah yang dilakukan secara parate eksekusi maka hal tersebut tidakideal untuk tercapainya kepastian hukum karena tidak sesuai dengan Undang-Undang Nomor 4 Tahun 1996 Tentang Hak Tanggungan atas Tanah Beserta Benda-benda yang Berkaitan dengan Tanah Penjelasan Umum Angka 9 dan Buku Standar Operasional Musyarakah OJK, "BUS/UUS/BPRS tidak diperkenankan melakukan eksekusi langsung. Seharusnya pihak bank mengajukan permohonan eksekusi terlebih dahulu kepada Pengadilan Agama dan selanjutnya pengadilan agama menindak lanjutinya selayaknya eksekusi putusan yang telah berkekuatan hukum tetap. (Shofa Fathiyah dan Nurhasanah, 2019). Meskipun dalam pembiayaan musyarakah dan mudharabah menggunakan prinsip yang berlandaskan syariat Islam, selalu ada permasalahan yang muncul di dalamnya. Salah satu permasalahan yang sering menjadi problematika adalah diperbolehkannya meminta jaminan dari nasabah ketika memberikan pembiayaan. Padahal jelas jumhur ulama menyepakati bahwa shahibul maal tidak diperbolehkan meminta jaminan kepada nasabah pembiayaan/mitra. Bank syariah menerapkan adanya jaminan untuk memastikan bahwa modal yang disalurkan dan keuntungan yang diharapkan dapat tercapai sesuai dengan syarat-syarat yang telah ditentukan dalam kontrak. (Khamidah Nurzahiroh, 2018)

\section{Metode Penelitian}

Penelitian artikel ini menggunakan pendekatan normatif. Pendekatan normatif digunakan untuk riset dari perspektif fikih muamalat tentang kedudukan jaminan dalam akad mudharabah dan akad musyarakah. Data diperoleh melalui penelusuran pustaka (library research). Analisis data yang dilakukan secara kualitatif terhadap semua sumber literature. Dengan analisis data yang objektif dan reliabel diharapkan akan diperoleh pembahasan akurat dan valid sebagai jawaban terhadap semua rumusan masalah yang telah dibuat dalam penelitian ini. 


\section{Hasil dan Pembahasan}

\section{Jaminan Dalam Hukum Syariah}

Ahli-ahli hukum konvensional membedakan jaminan dari segi sifatnya menjadi (1) jaminan umum, dan (2) jaminan khusus. Jaminan umum dimaksudkan bentuk jaminan yang ditetapkan oleh undang-undang bagi kepentingan para kreditur secara umum bahwa semua kekayaan yang dimiliki oleh seseorang (dalam hal ini debitur) merupakan jaminan atas segala perikatan dan perhutangan yang dibuatnya. Sementara itu, jaminan khusus adalah jaminan dalam bentuk penunjukan atau penyerahan barang tertentu secara khusus sebagai tanggunggan atas pelunasan kewajiban debitur kepada kredutur tertentu yang hanya berlaku utuk kreditur tertentu tersebut. Jaminan khusus pada gilirannya dibedakan lagi menjadi (a) jaminan perseorangan, dan (b) jaminan kebendaan. Jaminan perorangan adalah jaminan yang di berikan oleh seorang penanggung kepada kreditur untuk melunasinya kewajiban debitur apabila debitur bersangkutan tidak melunasinya saat kewajiban itu jatuh tempo. Sedangkan jaminan kebendaan adalah jaminan dalam bentuk benda yang bernilai ekonomis yang diserahkan seorang debitur kepada kreditur sebagai tanggungan atas utangnya, dalam arti bahwa apabila ia tidak dapat melunasi hutang tersebut pembayarannya dilakukan dengan mengeksekusi benda tersebut. Hukum tidak menentukan jenis-jenis benda yang dapat dijadikan jaminan kebendaan, sehingga dapat berupa benda bergerak atau tidak bergerak, benda berbadan atau tidak berbadan.

Meskipun ahli-ahli hukum Islam tidak membuat kategorisasi jaminan sebagaimana disebut di atas, namun kategorisasi itu dapat diterapkan dalam hukum Islam karena unsur-unsur kategorisasi tersebut ada dalam sistem hukum ini. Mengenai jaminan umum yang menegaskan bahwa seluruh kekayaan seseorang adalah jaminan bagi perikatan-perikatan yang dibuatnya, dalam hukum Islam asas ini juga merupakan prinsip penting. Hal ini tercermin dalam ketentuan Hukum Islam bahwa kewajiban-kewajiban pewaris tidak dialihkan kepada ahli waris. Kewajiban pewaris dibebankan sepenuhnya kepada harta kekayaan yang ditinggalkannya. Dalam hukum Islam apabila seseorang meninggal dunia, maka dengan kematiannya semua kewajiban 
keuangannya yang belum jatuh tempo menjadi jatuh tempo secara otomatis dan dilunasi dengan harta yang ditinggalkannya. Hak-hak kreditur dan penerima wasiat didahulukan atas hak-hak ahli waris. Ini adalah penerapan dari asas bahwa semua harta kekayaan seseorang menjadi jaminan atas perikatan-perikatan yang dibuatnya. Asas ini dicantumkan dalam berbagai KUH Perdata Syariah yang ada di dunia.

Jaminan perorangan dikenal dengan istilah kafalah dalam hukum Islam. Dengan kafalah dimaksudkan, "Penggabungan tanggung jawab penjamin (kafil) kepada tanggung jawab terjamin dalam menghadapi tagihan berupa penyerahan orang, pembayaran hutang, atau pengembalian benda". Berdasarkan definisi ini ada tiga macam kafalah, yaitu (1) kafalah untuk menjamin orang (agar tidak melarikan diri misalnya), (2) kafalah untuk menjamin hutang, dan (3) kafalah untuk menjamin pengembalian benda (misalnya jaminan oleh seseorang penanggung bahwa benda yang dipinjam atau disewa oleh seseorang akan dikembalikan kepada pemiliknya atas jaminan penanggung).

Jaminan kebendaan dalam hukum Islam terwujud rahan (ar-rahn). Rahan mempunyai dua pengertian: pengertian dalam arti kata kerja dan pengertian dalam arti kata benda. Dalam arti kata kerja, rahan adalah "menjadikan suatu benda yang mempunyai nilai ekonomis dalam pandangan syariah sebagai jaminan hutang dari mana diambil pembayaran seluruh atau sebagian hutang itu". Menurut Standar Syariah Nomor 39 yang dikeluarkan oleh AAOIFI, rahan adalah "menjadikan suatu benda bernilai ekonomis sebagai jaminan hutang yang dari padanya atau dari harganya hutang itu dibayarkan manakala si berhutang tidak melunasinya". Dalam arti kata benda rahan adalah, "benda bernilai ekonomis dalam pandangan syariah yang dijadikan jaminan atas hutang debitur terhadap kreditor". Dalam Hukum Perdata Syariah Kontemporer rahan dibedakan menjadi bermacam-macam selaras dengan perkembangan doktrin hukum modern. Ada rahan tasjili (jaminan fidusia), ada rahan takmini (hak tanggungan), dan ada rahan hiyazi (gadai biasa).

Dalam Standar Syariah Nomor 5 angka 6.1 s/d angka 6.5 disebutkan beberapa bentuk lain jaminan, yaitu berupa garansi bank, dokumen kredit, penggunaan cek dan surat sanggup, asuransi hutang, dan rekening yang diblokir. Dalam Hukum Islam perjanjian penjaminan terhadap suatu perikatan 
merupakan perjanjian asesoir (tab'i) yang mengikuti kepada perjanjian pokoknya. Perjanjian penjaminan ini dalam hukum Islam termasuk ke dalam apa yang disebut dengan syarat buatan (asy-syart al-ja'li), yakni syarat (klausul) yang dibuat oleh para pihak sendiri. Syarat buatan ada tiga macam. Salah satu di antaranya yang paling penting adalah apa yang disebut sebagai syarat penyerta akad (asy-syart al-muqtarin bin al-'aqd). Syarat-syarat penyerta akad itu adalah klausul yang dimasukkan oleh para pihak ke dalam akad sesuai dengan kepentingannya. Syarat-syarat penyerta akad itu ada yang sah diperjanjikan dan ada yang tidak sah diperjanjikan. Syarat penyerta akad yang tidak sah adalah syarat yang bertentangan dengan syariah. Sedangkan syarat penyerta akad yang sah diperjanjikan itu meliputi:

a. Syarat yang merupakan konsekuensi akad, sehingga diperjanjikan atau tidak diperjanjikan syarat ini berlaku karena merupakan konsekuensi akad itu sendiri, seperti pemberi sewa mensyaratkan agar barang sewa dikembalikan kepada penyewa begitu masa sewa berakhir. Kewajiban mengembalikan barang sewa setelah selesai masa sewa merupakan kosenkuensi akad itu sendiri, sehingga diperjanjikan atau tidak, kewajiban tersebut tetap berlaku.

b. Syarat selaras dengan akad, yakni syarat yang bertujuan untuk mendukung dan memperkuat akad. Syarat ini dalam hukum perikatan syariah meliputi syarat memberikan kafalah (jaminan personal) atau rahan (jaminan kebendaan).

c. Syarat yang sudah berlaku dalam praktik masyarakat, yakni klausul yang tidak termasuk kategori pertama dan kedua, namun telah lazim diperjanjian dalam masyarakat.

d. Syarat yang mengandung kemaslahatan bagi masing-masing pihak sesuai kepentingan masing-masing.

Memperjanjikan syarat-syarat penyerta akad dalam hukum Islam termasuk wilayah kebebasan berakad, dalam arti para pihak (khususnya kreditur) bisa saja meminta klausul adanya jaminan kebendaan (rahan) dalam akad yang menimbulkan hutang. Hal ini sesuai dengan kaidah (asas) hukum Islam yang menegaskan, "pada asasnya akad adalah kesepakatan para pihak dan akibat hukumnya adalah apa yang mereka tetapkan atas diri 
mereka melalui janji". Hanya saja ada ketentuan dalam hukum Islam bahwa penyaratan rahan atau kafalah dalam akad-akad amanah tidak diperkenankan seperti akad wakalah, akad wadiah, akad ijarah, akad musyarakah dan akad mudarabah, kecuali untuk menjamin kerugian dalam kasus-kasus perbuatan melanggar hukum, kealpaan, dana tau pelanggaran kontrak.

Dalam ketentuan fikih, pada akad-akad amanah aset yang menjadi objek akad tersebut adalah amanah di tangan pemegangnya. Tangan pemegang aset yang menjadi amanah di tangannya itu di sebut yad al-amanah (tangan pemegang amanah). Misalnya pada akad wadiah di mana seseorang menitipkan suatu benda kepada orang lain berdasarkan akad wadiah, maka benda tersebut merupakan amanah di tangan penerima titipan. Begitu pula pada akad ijarah, barang sewaan di tangan penyewa merupakan amanah. Termasuk pula modal di tangan sekutu (syarik) dalam akad musyarakah atau di tangan pelaku usaha (mudarib) dalam akad mudarabah adalah amanah. Oleh karena itu tangan penerima titipan, penyewa, syarik, atau mudarib adalah tangan pemegang amanah (yad al-amanah). Hal ini berarti bahwa apabila aset yang merupakan amanah di tangan mereka itu rusak atau musnah bukan karena karena kesalahan pemegang amanah atau kealpaan dalam menjaga amanah itu. Dalam hal ini al-Kharasyi (w. 1101/1689), seorang ulama Maliki, menegaskan bahwa, "benda amanah apabila hilang atau rusak tidak ada kewajiban atas pemegangnya untuk menggantinya". Oleh karena itu benda titipan atau modal di tangan pelaku usaha (mudarib) atau sekutu (syarik) apabila hilang atau berkurang, bukan karena kesalahan atau kealpaan mereka, tidak dipertanggung jawabkan kepada mereka.

Namun demikian, komentator al-Kharasyi yang bernama Syeikh 'Ali al-'Adawi (w.1189/1774) mengulas pernyataan al-Kharasyi bahwa boleh mengambil rahan kebendaan atas suatu akad amanah sebagai jaminan atas kerusakan obyek akad amanah di tangan pemegangnya yang disebabkan karena kelalaian atau pelanggaran yang dilakukannya. Dalam hal ini Syeikh 'Ali al-'Adawi menegaskan, "adapun apabila ia mengambil jaminan dengan ketentuan apabila barang amanah hilang karena kelalaian pemegangnya, di jaminan dieksekusi karenanya, maka hal itu sah". Artinya, menurut Syeikh 'Ali al-'Adawi, sah mengambil jaminan untuk menjamin akad-akad amanah terhadap bahaya moral yang mungkin dilakukan oleh pemegang amanah. Ini adalah norma 
dalam fikih Maliki. Dan apa yang dipegangi oleh ulama-ulama Maliki ini juga menjadi pendapat yang diterima dan diakui dalam mazhab Hanafi dan Hanbali. Dalam Durar al-Hukkam fi Syarh Majallat al-Ahkam, ditegaskan bahwa "tidak boleh mengambil jaminan kebendaan terhadap sesuatu yang murni amanah dan tidak dijamin, seperti......modal mudarabah dan syirkah; apabila dimintakan jaminan kebendaan (rahan), atas aset-aset ini maka rahan itu batal......akan tetapi apabila barang amanah tersebut digunakan atau musnah karena pelanggaran atau karena kealpaan, maka sifat amanah barang tersebut menjadi hilang dan akad itu berubah menjadi akad yang dijamin". Artinya menurut "Ali Haidar, boleh mengambil jaminan kebendaan atas akad mudarabah dan musyarakah sebagai jaminan terhadap kealpaan atau pelanggaran yang mungkin dilakukan oleh pemegang amanah seperti mudarib atau syarik.(Syamsul Anwar, 2020)

\section{Mudharabah}

a. Pengertian Mudharabah

Mudharabah berasal dari kata dharb, yang secara etimologis berarti bepergian atau berjalan. Al-Qur'an tidak secara langsung menunjukan arti dari mudharabah tersebut. Namun secara implisit, kata dasar dha-ra-ba yang merupakan kata dasar mudharabah disebutkan di dalam AlQur'an sebanyak lima puluh delapan kali.(OJK (Otoritas Jasa Keuangan), n.d.). Mudharabah adalah suatu kontrak kemitraan (patnership) yang berlandaskan pada prinsip bagi hasil dengan cara seseorang memberikan modalnya kepada orang lain untuk melakukan bisnis dan kedua belah pihak membagi keuntungan atau memikul beban kerugian berdasarkan isi perjanjian bersama. Diperdagangkan orang lain dan memotong labanya. Disebut juga muamalat yaitu akad antara dua belah pihak, dimana salah satu pihak menyerahkan uang kepada pihak lain untuk diperdagangkan olehnya, sedangkan labanya dibagi antara mereka berdua menurut kesepakatan mereka bersama. (Syafi'I Jafri, 2000)

Mudharabah adalah akad yang telah dikenal oleh umat muslim sejak zaman Nabi, bahkan telah dipraktekkan oleh bangsa arab sebelum turunnya Islam. Ketika Nabi Muhammad SAW berprofesi sebagai pedagang yang kala itu Nabi Muhammad SAW berusia kira-kira 20- 
25 tahun dan belum menjadi Nabi, beliau melakukan akad mudharabah dengan khadijah (Adiwarman A Karim, 2006).

b. Landasan Hukum Mudharabah

Namun demikian, ada ayat-ayat yang walaupun tidak langsung, tetapi maksudnya dapat digunakan sebagai dasar atau landasan kebolehan mudharabah, seperti ayat-ayat tentang perintah mencari karunia Allah SWT, diantaranya adalah firman Allah yang artinya;

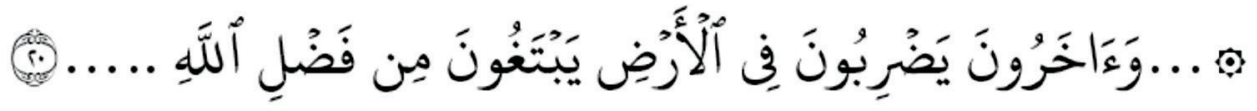

"Dan orang-orang yang berjalan dimuka bumi mencari sebagian karunia Allah." (QS. Al-Muzammil, (73): 20)

Ayat tersebut menjelaskan bahwa sebagai manusia yang hidup dimana, maka kiranya senantiasa mencari rizki (karunia Allah) dengan bermuamalah, salah satunya yaitu dengan kerjasama antara manusia. Didalam Al-Qur'an, termasuk dalam ayat diatas memang tidak ada secara tegas menerangkan tentang pelaksanaan mudharabah, tetapi dari berbagai ayat tentang muamalat, dapat diambil kesimpulan bahwa untuk bekerja sama mudharabah diperbolehkan. Dasar hukum mudharabah yang kedua adalah al-Sunnah. Selain al-Quran, hadits sebagai salah satu sumber hukum Islam juga memberikan landasan tentang mudharabah, atau qiradh. Adapun hadits tentang mudharabah atau qirdh yang artinya;

"Hadits dari Hasan bin Ali al-Khallal, Hadits dari Basyar bin Tsabit alBazar, hadits dari Natsir bin al-Qosim dari Abdurrahman (Abdurrohim) bin Dawud dari Shalih bin Shuhaib dari Ayahnya, berkata rosulullah SAW, bersabda: Tiga hal yang didalamnya ada berkah, jual beli yang temponya tertentu, muqaradlah (nama lain dari mudharabah) dan mencampur antara burr dengan syair untuk rumahtangga, bukan untuk dijual." (HR. Ibnu Majah).

Dasar mudharabah yang ketiga adalah Ijma'. Berdasarkan Ijma' golongan sahabat yang sesungguhnya tidak menolak harta anak yatim untuk dilakukan mudarabah yang berdasarkan npada ijtihad Umar bin Khattab. Diriwayatkan Abdillah bin Zaid bin Aslam yang mengatakan bahwa Abdullah dan Ubaidillah putra-putra Umar bin Khattab r.a 
keluar bersama pasukan Irak. Ketika mereka kembali mereka singgah pada bawahan Umar yaitu Musa al-Asy'ari seorang Gubernur Basrah yang menerima mereka dengan senang hati berkata sekiranya aku dapat memberikan pekerjaan kepada kalian yang bermanfaat aku akan melakukannya kemudian ia berkata: sebetulnya bagian ini adalah sebagian dari harta Allah yang aku ingin kirimkan kepada Amirul mu'minin. Aku pinjamkan kalian untuk dipakai membeli barang yang ada di Irak. Kemudian kalian jual di Madinah. Kalian serahkan modal pokoknya kepada Amirul mu'minin, dengan demikian kalian mendapatkan keuntungan. Keduanya berkata kami senang melakukannya kemudian Abu Musa melakukannya dan menulis surat kepada Umar agar beliau mengambil harta dari keduanya. Setelah mereka tiba, mereka menjual barang tersebut dan mendapatkan keuntungan, Umar berkata adakah semua pasukan telah pinjamkan uang seperti kamu? Mereka menjawab tidak, kemudian Umar berkata dua anak amirul mu'minin, karena mereka meminjamkan kepada keduanya, serahkanlah harta dan labanya. Abdullah diam saja, tetapi Ubaidillah menjawab wahai amirul mu'minin, kalau harta itu binasa (habis) kami menjaminnya. Umar terus berkata serahkanlah, Abdullah diam saja dan Ubaidillah mendapatkannya. Salah seorang yang hadir di majelis Umar tersebut berkata wahai amirul mu'minin bagaimana sekiranya harta itu anda anggap qiradh? Umar lantas menyetujui pendapat ini dan mengambil modal setengah dari labanya (Az-Zuhaily 2001, 839).(Rika Anggraini, 2020)

Dasar mudharabah yang keempat adalah qiyas. Mudharabah dapat diqiyaskan (analogi) kepada transaksi musaqat, yaitu bagi hasil yang umum dilakukan dalam bidang perkebunan. Dalam hal, pemilik kebun bekerja sama dengan orang lain dengan pekerjaan menyiram, memelihara dan merawat isi kebun. Dalam, perjanjian ini sang perawat (penyiram) mendapatkan bagi hasil tertentu sesuai dengan kesepakatan di depan dari out put perkebunan (pertanian).(Dimyauddin Djuwaini, 2008)

c. Syarat dan Rukun

Sebagai sebuah akad, mudharabah memiliki syarat dan rukun. 
Imam An-Nawawi menyebutkan bahwa Mudharabah memiliki lima rukun:

1) Modal

2) Jenis usaha

3) Keuntungan

4) Shighot (pelafalan transaksi)

5) Dua pelaku transaksi, yaitu pemilik modal dan pengelola. (ArRaudhah karya imam Nawawi (5/117))

Sedangkan syarat-syarat dalam Mudharabah ialah sebagaimana berikut:

1) Penyedia dana (sahibul maal) dan pengelola (mudharib) harus cakap hukum.

2) Pernyataan ijab dan qabul harus dinyatakan oleh para pihak untuk menunjukkan kehendak mereka dalam mengadakan kontrak (akad), dengan memperhatikan hal-hal berikut:

a) Penawaran dan penerimaan harus secara eksplisit menunjukkan tujuan kontrak (akad).

b) Penerimaan dari penawaran dilakukan pada saat kontrak.

c) Akad dituangkan secara tertulis, melalui korespondensi, atau dengan menggunakan cara-cara komunikasi modern.

3) Modal ialah sejumlah uang dan/atau aset yang diberikan oleh penyedia dana kepada pengelola (mudharib) untuk tujuan usaha dengan syarat sebagai berikut:

a) Modal harus diketahui jumlah dan jenisnya.

b) Modal dapat berbentuk uang atau barang yang dinilai. Jika modal diberikan dalam bentuk aset, maka aset tersebut harus dinilai pada waktu akad.

c) Modal tidak dapat berbentuk piutang dan harus dibayarkan kepada mudharib (pengelola modal), baik secara bertahap maupun tidak, sesuai dengan kesepakatan dalam akad.

4) Keuntungan mudharabah adalah jumlah yang didapat sebagai kelebihan dari modal. Syarat keuntungan berikut ini harus dipenuhi: 
a) Harus diperuntukkan bagi kedua pihak dan tidak boleh disyaratkan hanya untuk satu pihak.

b) Bagian keuntungan proporsional bagi setiap pihak harus diketahui dan dinyatakan pada waktu kontrak disepakati dan harus dalam bentuk prosentasi (nisbah) dari keuntungan sesuai kesepakatan. Perubahan nisbah harus berdasarkan kesepakatan.

c) Penyedia dana menanggung semua kerugian akibat dari mudharabah, dan pengelola tidak boleh menanggung kerugian apapun kecuali diakibatkan dari kesalahan disengaja, kelalaian, atau pelanggaran kesepakatan.

5) Kegiatan usaha oleh pengelola (mudharib), sebagai perimbangan modal yang disediakan oleh penyedia dana, harus memperhatikan hal-hal berikut:

a) Kegiatan usaha adalah hak eksklusif pengelola (mudharib), tanpa campur tangan penyedia dana, tetapi ia mempunyai hak untuk melakukan pengawasan.

b) Penyedia dana tidak boleh mempersempit tindakan pengelola sedemikian rupa yang dapat menghalangi tercapainya tujuan mudharabah, yaitu keuntungan.

c) Pengelola tidak boleh menyalahi hukum Syariah Islam dalam tindakannya yang berhubungan dengan mudharabah, dan harus mematuhi kebiasaan yang berlaku dalam aktifitas itu.(Heru Maruta, 2016)

Menurut Kompilasi Hukum Ekonomi Syariah (KHES) Pasal 231 syarat mudharabah yaitu sebagai berikut:

1) Pemilik modal wajib menyerahkan dana dan atau barang yang berharga kepada pihak lain untuk melakukan kerjasama dalam usaha.

2) Penerima modal menjalankan usaha dalam bidang yang disepakati.

3) Kesepakatan bidang usaha yang akan dilakukan ditetapkan dalam akad.(Mahkamah Agung Republik Indonesia Direktorat Jenderal Badan Peradilan Agama, 2011) 
Menurut Kompilasi Hukum Ekonomi Syariah (KHES) rukun mudharabah yaitu sebagai berikut:

1) Pasal 232

Rukun kerjasama dalam modal dan usaha adalah:

a) Shahib al-mal/pemilik modal

b) Mudharib/pelaku usaha

c) Akad

2) Pasal 233

Kesepakatan bidang usaha yang akan dilakukan dapat bersifat mutlak/bebas dan muqayyad/terbatas pada bidang usaha tertentu, tempat tertentu dan waktu tertentu. (Mahkamah Agung Republik Indonesia Direktorat Jenderal Badan Peradilan Agama, 2011)

d. Jenis-jenis

Ada dua jenis mudharabah adalah:

1) al-Mudharabah al-muqayyadah (resticted mudharabah). Disebut almudharabah al-muqayyadah atau mudharabah yang penyerahan modal dengan syarat dan batas tertentu. Maksudnya, pekerja harus mengikuti syarat-syarat dan batasan-batasan yang dikemukakan oleh pemilik modal.

2) al-Mudharabah al-muthlaqah (unrestricted mudharabah). Disebut almudharabah al-muqayyadah atau mudarabah yang penyerahan modal secara mutlak, tanpa syarat dan pembatasan. Maksudnya, pekerja beba mengelola modal itu dengan usaha apa saja yang ia inginkan. (Nasrun Haroen, 2007)

Adapun jenis mudharabah muqayyadah terbagi menjadi dua, yaitu:

1) Mudharabah muqayyadah on balance sheet

Mudharabah muqayyadah on balance sheet (investasi terikat) yaitu pemilik dana (shahibul maal) membatasi atau memberi syarat kepada mudharib dalam pengelolaan dana seperti misalnya hanya melakukan mudharabah bidang tertentu, cara, waktu dan tempat tertentu saja. 
2) Mudharabah muqayyadah of balance sheet

Mudharabah muqayyadah of balance sheet ini merupakan jenis mudharabah di mana penyaluran dana mudharabah langsung kepada pelaksana usahanya, di mana bank bertindak sebagai perantara (arranger) yang mempertemukan antara pemilik dana dengan pelaksana usaha. Pemilik dana dapat menetapkan syarat-syarat tertentu yang harus dipatuhi oleh bank dalam mencari kegiatan usaha yang akan dibiayai dan pelaksanaan usahanya.(Maghfur Wahid, 2015)

\section{Musyarakah}

a. Pengertian Musyarakah

Menurut bahasa, musyarakah adalah bercampurnya suatu harta dengan harta yang lain sehingga keduanya tidak bisa dibedakan lagi. Sedangkan menurut istilah para ulama fiqh berbeda pendapat dalam mengartikan istilah musyarakah. Menurut ulama Malikiyah, musyarakah adalah pemberian izin kepada kedua mitra kerja untuk mengatur harta atau modal bersama. Maksudnya, setiap mitra memberikan izin kepada mitranya yang lain untuk mengatur harta keduanya tanpa kehilangan hak untuk melakukan hal itu. Menurut ulama Hambali, musyarakah adalah persekutuan hak atau pengaturan harta. Menurut ulama Syafi'i, musyarakah adalah tetapnya hak kepemilikan bagi dua orang atau lebih sehingga tidak terbedakan antara hak pihak yang satu dengan pihak yang lain. Menurut ulama Hanafi, musyarakah adalah transaksi antara dua orang yang bersekutu dalam modal dan keuntungan. Ini adalah definisi yang paling tepat bila dibandingkan dengan definisi-definisi yang lain, karena definisi ini menjelaskan hakikat musyarakah, yaitu sebuah transaksi.(Syafi'I Rahmat, 2001)

b. Landasan Hukum Musyarakah

1) Alquran

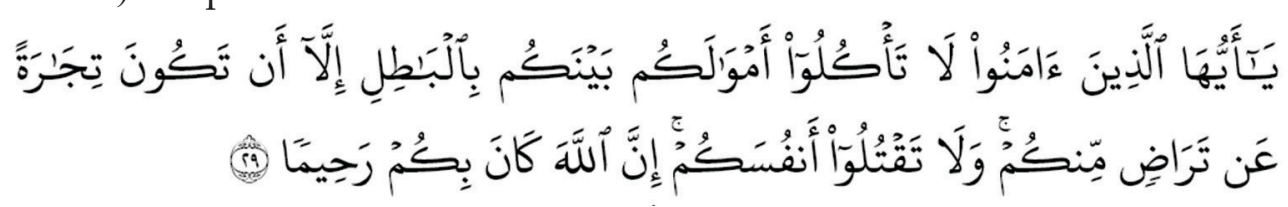


Artinya: "Hai orang-orang yang beriman, janganlah kamu saling memakan harta sesamamu dengan jalan yang batil, kecuali dengan jalan perniagaan yang berlaku dengan suka sama-suka di antara kamu. Dan janganlah kamu membunuh dirimu; sesungguhnya Allah adalah Maha Penyayang kepadamu" (Q.S An-Nisaa': 29)

2) Hadis

a) "Dari Abu Hurairah, Rasulullah saw. bersabda, "Sesungguhnya Allah Azza wa Jalla berfirman, "aku pihak ketiga dari dua orang yang berserikat selama salah satunya tidak mengkhianati lainnya." (HR Abu Dawud no. 2936, dalam kitab al-Buyu, dan Hakim)

b) "Allah akan ikut membantu doa untuk orang yang berserikat, selama di antara mereka tidak saling mengkhianati." (HR. Bukhari)

3) Ijma'

Ibnu Qudamah dalam kitabnya Al-Mughni telah berkata, "kaum muslimin telah berkonsensus terhadap legitimasi musyarakah secara global walaupun terdapat perbedaan pendapat dalam hal elemen darinya" (Khamidah Nurzahiroh, 2018).

c. Syarat dan Rukun Musyarakah

1) Ijab dan qabul

Ijab dan qabul harus dinyatakan dengan jelas dalam akad dengan memperhatikan hal-hal sebagai berikut :

a) Penawaran dan permintaan harus jelas dituangkan dalam tujuan akad.

b) Penerimaan dan penawaran dilakukan pada saat kontrak.

c) Akad dituangkan secara tertulis.

2) Pihak yang Berserikat

a) Kompeten.

b) Menyediakan dana sesuai dengan konrak pekerjaan atau proyek usaha.

c) Memiliki hak untuk ikut mengelola bisnis yang sedang dibiayai ataumemberi kuasa kepada mitra kerjanya untuk mengelolahnya. 
d) Tidak diizinkan mengggunakan dana untuk kepentingan sendiri.

3) Objek Akad

a) Modal

(1) Modal dapat berupa uang tunai atau asset yang dapat dinilai. Bila modal dalam bentuk aset, maka asset ini sebelum kontrak harus dinilai dan disepakati oleh masing-masing mitra.

(2) Modal tidak boleh dipinjamkan atau dihadirkan ke pihak lain.

(3) Pada prinsipnya bank syariah tidak harus minta agunan, akan tetapi untuk menghindari wansprestasi, maka bank syariah diperkenankan meminta agunan dari nasabah atau mitra kerja.

b) Kerja

(1) Partisipasi kerja dapat dilakukan bersama-sama dengan porsi kerja yang tidak harus sama, atau salah satu mitra memberi kuasa kepada mitra kerja lain-lainnya untuk mengelola usahanya.

(2) Kedudukan masing-masing mitra harus tertuang dalam kontrak.

c) Keuntungan atau Kerugian

(1) Jumlah keuntungan harus dikuantifikasikan.

(2) Pembagian keuntungan harus jelas dan tertuang dalam kontrak. Bila rugi, maka kerugian akan ditanggung oleh masing-masing mitra berdasarkan porsi modal yang diserahkan.(Muklis, 2015).

d. Jenis-jenis Musyarakah

Menurut H. Syafi'i Antonio (2001:91) jenis-jenis musyarakah ada dua, yaitu: musyarakah pemilikan dan musyarakah akad (kontrak). Musyarakah pemilikan tercipta karena warisan, wasiat, atau kondisi lainnya yang mengakibatkan pemilkan satu aset oleh dua orang 
atau lebih berbagi dalam sebuah aset nyata dan berbagi pula dari keuntungan yang dihasilkan aset tersebut. Adapun akad musyarakah tercipta dengan cara kesepakatan di mana dua orang atau lebih setuju bahwa tiap orang dari mereka memberikan modal musyarakah. Dan mereka pun sepakat berbagi keuntungan dan kerugiannya.

Menurut Mahmud Syaltut dalam Masjfuk Zuhdi (1992:113) ada empat macam akad syirkah dalam musyarakah antara lain: al-'inan, al-mufawadhah, al-wujuh, dan al-mudharabah.

1) Syirkah al-inan adalah kerja sama antara dua orang atau lebih dalam permodalan untuk melakukan suatu bisnis atas dasar membagi rugi sesuai dengan jumlah modal masing-masing.

2) Syirkah al-Mufawadhah adalah kerja sama antara dua orang atau lebih untuk melakukan suatu usaha dengan modal uang atau jasa dengan syarat sama modalnya, agamanya, mempunyai wewenang melakukan perbuatan hukum.

3) Syirkah al-Wujuh adalah kerja sama dua orang atau lebih untuk membeli sessuatu tanpa modal uang, tetapi hanya berdasarkan kepercayaan para pegusaha dengan perjanjian profit.

4) Syirkah al-Mudharabah beberapa Ulama membahas mudharabah secara tersendiri dan memisahkan dari bab "syirkah".(Miswanto, 2018)

\section{Simpulan}

Berdasarkan apa yang dikemukakan di atas tentang bolehnya meminta jaminan atas akad-akad amanah, termasuk akad-akad bagi hasil (seperti mudarabah dan musyarakah), maka dalam fatwa-fatwa mengenai lembaga keuangan syariah, dibolehkan lembaga-lembaga tersebut menarikjaminan atas akad-akad bagi hasil yang mereka tutup bersama nasabahnya. Dalam Standar Syariah Nomor 5, ditegaskan bahwa: Tidak diperkenankan mensyaratkan kafalah (jaminan perseorangan) atau rahan (jaminan kebendaan) dalam akad-akad amanah, seperti akad wakalah dan wadiah, karena pensyaratan rahan (jaminan kebendaan) dalam akad-akad tersebut bertentangan dengan konsekuensi akad tersebut, selama pensyaratan tersebut tidak dibatasi pada kasus pelanggaran hukum, kealpaan, dan 
pelanggaran ketentuan kontrak. Lebih khusus lagi, dalam akad-akad musyarakah dan mudarabah tidak diperkenankan mensyaratkan jaminan kepada mudarib atau mitra usaha atau manajer investasi, baik jaminan itu atas modal maupun keuntungan. Akad-akad ini tidak diperkenankan untuk dioperasionalisasikan dan dipasarkan sebagai kontrak-kontrak yang dijamin.

Hal yang sama ditegaskan dalam Standar Syariah Nomor 39 secara lebih singkat: Tidak boleh mensyaratkan rahan (jaminan kebendaan) dalam akad-akad amanah, seperti akad wakalah, wadiah, musyarakah, mudarabah, dan atas barang sewaan di tangan penyewa. Jika pengambilan rahan (jaminan kebendaan) itu untuk menutupi kerugian karena perbuatan melanggar hukum, kealpaan atau pelanggaran kontrak, maka hal itu diperkanankan. Ketentuan seperti dikemukakan di atas juga diadopsi dalam fatwa Dewan Syariah Nasional (DSN) yang dikeluarkan tahun 2016 dalam mana ditegaskan, yakni: pertama, pengelola tidak wajib mengembalikan modal usaha secara penuh pada saat terjadi kerugian, kecuali kerugian karena ta'addi, tafrith atau mukhalafat al-syuruth. Kedua, pemilik modal tidak boleh meminta pengelola untuk menjamin pengembalian modal. Ketiga, pengelola boleh menjamin pengembalian modal atas kehendaknya sendiri tanpa permintaan dari Pemilik Modal. Keempat, pemilik Modal boleh meminta pihak ketiga untuk menjamin pengembalian modal.

Dari apa yang dikemukakan di atas dapat dilihat bahwa pada dasarnya tidak ada jaminan atas akad-akad bagi hasil, seperti mudarabah dan musyarakah, kecuali sebagai jaminan atas kemungkinan adanya moral hazard (bahaya moral) yang dilakukan oleh mitra akad. Dalam fatwa DSN tentang mudarabah dan tentang musyarakah ditegaskan bahwa: Jaminan (ganti rugi) dalam kedua akad itu karena merupakan akad amanah, namun untuk mengantisipasi terjadinya penyimpangan, LKS dapat menarik jaminan. Dalam praktik, lembaga-lembaga keuangan syariah, khususnya perbankan syariah, selalu menarik jaminan kebendaan atas akad-akad bagi hasil yang ditutupinya bersama mitranya (nasabahnya). Tetapi harus diingat bahwa penarikan jaminan kebendaan tersebut haruslah dibatasi pada kasus-kasus di mana adanya kerugian karena perbuatan melanggar hukum, kealpaan atau cedera janji yang dilakukan oleh nasabah. Dalam hal kerugian terjadi di luar kesalahan, kealpaan, atau pelanggaran kontrak oleh nasabah, maka jaminan tidak boleh dieksekusi. Oleh itu penarikan jaminan yang dilakukan oleh lembaga keuangan 
syariah kepada nasabahnya dalam akad-akad bagi hasil haruslah diartikan: pertama, sebagai pendorong bagi nasabah agar bersungguh-sungguh dalam mengelola usaha yang diamanahkan kepadanya agar tidak terjadi kerugian. Kedua, sebagai antisipasi bahwa apabila terjadi bahaya moral yang mungkin dilakukan seperti melakukan kesalahan, kealpaan atau pelanggaran kontrak. Dalam kasus ini jaminan dapat dieksekusi.

Dorongan kepada nasabah agar bersungguh-sungguh dalam mengelola usahanya adalah selaras dengan prinsip maslahat sebagai tujuan syariah (maqasid asy-syariah) di mana salah satu bagiannya adalah perlindungan harta kekayaan. Terlindunginya harta kekayaan menjadi salah satu butir tujuan syariah. Kita mengetahui bahwa dana yang dilempar oleh bank dalam bentuk pembiayaan untuk didayagunakan oleh nasabah sebagian besar merupakan dana pihak ketiga. Dana tersebut wajib dilindungi agar tidak tersia-siakan di tangan orang yang tidak bertanggung jawab. Salah satu sarana untuk perlindungan tersebut adalah meminta jaminan dari pengguna dana untuk bersungguh-sungguh mengelolanya dalam kegiatan usaha agar merugi dana agar tidak melakukan kealpaan dan pelanggaran dalam pengelolaan tersebut. Untuk menjamin hal itu, maka kepadanya dimintakan jaminan, di mana apabila ia melakukan kesalahan dan kealpaan serta pelanggaran kontrak ia harus bertanggung jawab dan untuk memudahkan pemenuhan tanggung jawab itu adalah dengan mengeksekusi jaminannya. Namun apabila ia telah berusaha keras sebagaimana mestinya dalam menjalankan usahanya, namun tetap rugi, maka jaminan tidak boleh dieksekusi. Prinsip syariah yang amat penting tertuang dalam hadis Nabi SAW yang menegaskan, “Tidak ada kerugian dan perugian" (HR. Ibn Majah). Artinya seseorang jangan tertimpa oleh kerugian, dan seseorang juga tidak boleh menimpakan kerugian kepada orang lain.(Syamsul Anwar, 2020)

\section{Daftar Rujukan}

Adiwarman A Karim. (2006). Bank Islam Analisis Fiqih dan Keuangan. Raja Grafindo Persada.

Dimyauddin Djuwaini. (2008). Fiqh Muamalah. Pustaka Pelajar.

Fajar dan Yanto. (2018). Mekanisme Eksekusi Barang Jaminan Pada Akad Musyarakah Di Bmt Ugt Sidogiri Bangkalan, ). KHOZANA: Jurnal 
Ekonomi Dan Perbankan Islam, Volume 1, 228.

Heru Maruta. (2016). Akad Mudharabah, Musyarakah, dan Murabahah Serta

Aplikasinya Dalam Masyarakat. IQTISHADUNA:Jurnal Ilmiah Ekonomi Kita, Volume 5 N, 83-84.

Khamidah Nurzahiroh. (2018). Kedudukan Jaminan Dalam Akad Pembiayaan Musyarakah Pada BPR Syariah Di Daerah Istimewa Yogyakarta.

Maghfur Wahid. (2015). Analisis Hukum Islam Terhadap Jaminan Pada Akad Pembiayaan Mudharabah (Studi Penerapan Fatwa DSN No. 07 DSN/MUI/ IV/Tahun 2000 Tentang Pembiayaan Mudharabah (Qiradah) di BMT Bismillah Sukorejo Kenda.

Kompilasi Hukum Ekonomi Syariah, 65 (2011).

Miswanto. (2018). Pengembangan Usaha Kecil Menengah Dengan Pembiayaan Musyarakah. Jurnal Studi Agama Islam, 65.

Muhyidin, M. M. S. dan T. (2017). Penerapan Beban Jaminan Akad Mudharabah Di Perbankan Syariah. Jurnal Hukum Perdata Diponegoro, Vol 1, No, 120121.

Muklis, S. F. (2015). Mudharabah, Murabahah, dan Musyarakah Pengaruhnya Terhadap Laba Bersih BUS di Indonesia. Jurnal Islaminomic, Vol. 6 No., 123-124.

Nasrun Haroen. (2007). Figh Muamalah (1st ed.). Gaya Media Pratama.

Nursakti, S. P. (2018). Jaminan Hak Tanggungan Pada Produk Pembiayaan Murabahah Dan Musyarakah Di Bank Muamalat Indonesia. Jurnal Ilmu Hukum, Volume 14, 83-84.

Seri Standar Produk Perbankan Syariah 5 Standar Produk Mudharabah, 15. Rika Anggraini. (2020). Jaminan dalam Pembiayaan Mudarabah Tinjauan Fatwa DSN-MUI Nomor 92 Tahun 2014. Ijtihad, Volume 36, 31.

Shofa Fathiyah dan Nurhasanah. (2019). Eksekusi Jaminan Hak Tanggungan

Nasabah Wanprestasi Akad Musyarakah Dalam Perspektif Perlindungan

Konsumen. Jurnal Hukum Replik, Volume 7 N, 78-79.

Syafi'I Jafri. (2000). Figh Muamalah (Cet. Ke-1). Susqa Press.

Syafi'I Rahmat. (2001). Fiqih Muamalah. Pustaka Setia.

Syamsul Anwar. (2020). Studi Hukum Islam Kontemporer (Bagian Dua) 164-169.

UAD Press. 